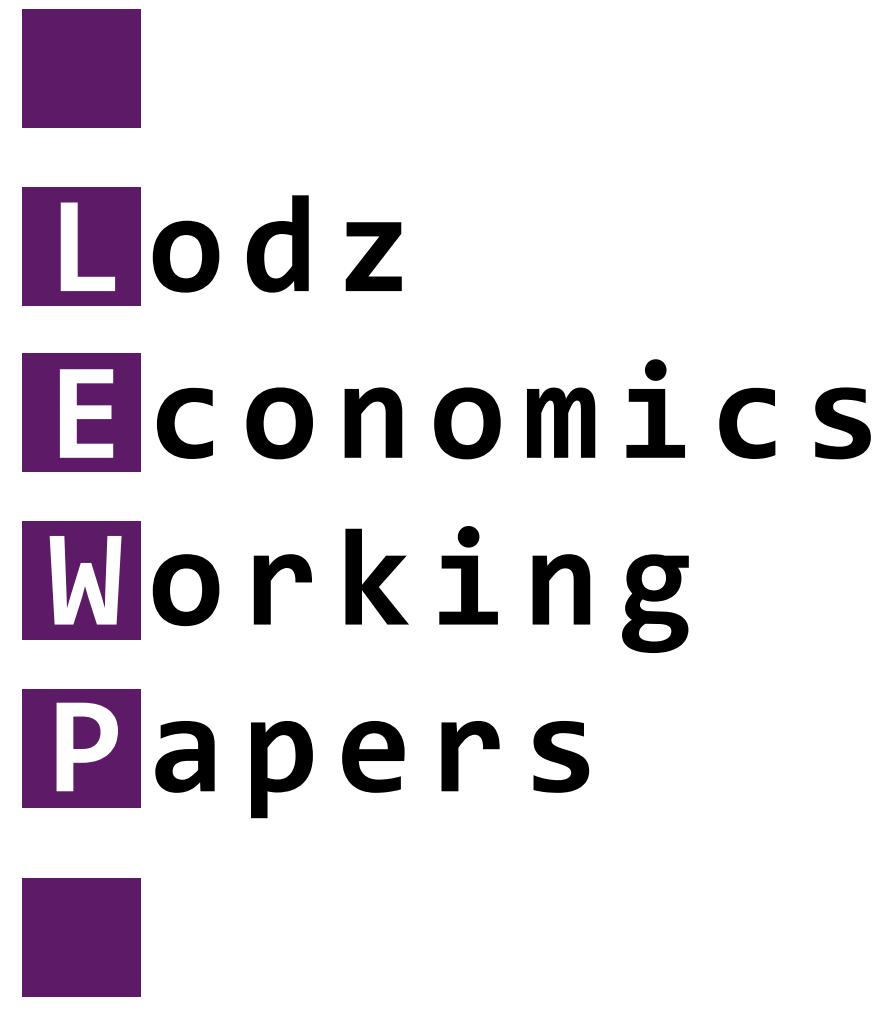

WHAT DRIVES EXPORT PERFORMANCE OF FIRMS IN EASTERN AND WESTERN
POLAND?

Paweł Gajewski Grzegorz Tchorek 


\title{
What drives export performance of firms in Eastern and Western Poland? ${ }^{1}$
}

\author{
Pawet Gajewski` and Grzegorz Tchorek*
}

\begin{abstract}
We use a unique firm-level survey dataset that draws from the EFIGE (European Firms In Global Economy) questionnaire, to unveil differences in factors driving export performance in structurally most diverse areas of Poland. While conventional results about the role of size, foreign ownership and innovation activity are confirmed at the aggregate level, the picture breaks down when Western and Eastern macroregions are extracted.

Our results suggest that the common perception of a more developed West (Poland " $\mathrm{A}$ ") and a backward East (Poland "B") might be outdated. Rather, firms in both regions seem to follow distinct strategies and have dissimilar success factors for competing internationally. Interestingly, export performance in the East is found to benefit from family ties in business, but also product innovation and non-price competitiveness. In the West, it is in turn associated mostly with size and foreign ownership. Overall, our results on the one hand add support to the 'New' new trade theory and 'New' new economic geography's premises related to the importance of microeconomic factors and, on the other, shed a new light on the pattern of regional development in Poland. We also discuss some implications for policy makers and managers and suggest directions of further research.
\end{abstract}

Keywords: trade, region, firm, competitiveness

JEL Classification: F14, R12

\footnotetext{
${ }^{1}$ This paper received funding from the National Science Center through grant no. DEC-2011/03/D/HS4/01954.

^Institute of Economic Sciences, Polish Academy of Sciences.

* University of Warsaw, Faculty of Management.
} 


\section{Introduction}

Export performance is one of the most closely watched yardsticks of a country's economic development. However, we should be aware of important weaknesses of the macroeconomic approach to diagnosing issues of international trade and its drivers. It might be misleading because it is concentrated on aggregated data and takes a too general view of economic processes (Altomonte et al., 2012). The 'New' new trade theory emphasizes and firm-level research confirms that we should think about competitiveness and international trade as well as more sophisticated forms of internationalization as a company's characteristics, not as a country-specific phenomenon (Melitz, 2003; Navaretti, 2010). In other words, these are firms, not countries, which trade and compete internationally, and export performance is more dependent on the companies' individual features than on the country where they operate.

True, the country-wide foundations of economic activity influence decisions taken in firms, but they are rather static in the short and medium run, framed by geographical location, legal framework and the slow-changing business environment. Leaving the constant geographical factors and uniform legal conditions aside, what seem interesting and under-researched are spatial disparities with respect to the business environment peculiarities. Indeed, there can be profound and persistent differences in structural determinants of export performance across regions. Industry-mix, competition intensity, proximity of external markets, access to transport infrastructure are but a few region-specific factors which can influence export strategies within firms. With its deeply rooted regionally diversified economic structures, Poland serves as a good laboratory to investigate their role in export performance determination.

Surprisingly, regional export performance has not been explored much when it comes to investigating company characteristics. Usually researchers use traditional macroeconomic variables like economic size of the region, foreign market access, quality of infrastructure and institutions and quality of labour resources in order to depict regional patterns (Naude and Gries, 2009; Ciżkowicz et al., 2013). In contrast, we explore individual firm data, largely consistent with the EFIGE survey, in order to draw a regional portrait of export determinants and assess whether the same company characteristics affect export performance in two most distinct areas of Poland. We concentrate on internal resource differences between companies expressing their abilities to export. We are interested in whether these features are similar in firms operating in structurally different regions. To some extent, we combine three strands of literature that consider the context of: international trade, regional development and international (family) business management. There, export performance is treated as a yardstick of productivity, competitiveness and internationalization capability, respectively. ${ }^{2}$

We expect that "unpacking" economic results into companies and local factors may give more indepth insights on features driving export performance than the aggregate approach (Békés and

\footnotetext{
${ }^{2}$ Exports is the most commonly used measure because of its simplicity and data availability. But Altomonte et al. (2012) and Navaretti et al. (2010) also distinguish important indicators of firms' competitiveness related to separate modes of internationalization such as indirect export (using intermediaries in export market penetration), direct export to small or big numbers of markets, exports to far-distance countries, exports of a big variety and number of products, scale of international outsourcing and outward FDls. More on determinants of FDI efficiency see e.g. Gorynia and Trąbczyński (2014).
} 
Ottaviano, 2016). Using company characteristics as a subject of the research, we expand the knowledge about an important element of regional competitiveness and innovativeness ecosystems. It may give some policy implications for central and local authorities in shaping their activity and mission as regions are defined as administrative NUTS_2 units (voivodships). The results may be also useful for managers and companies which to some extent rely on internationalization in their development strategy.

\section{Related literature}

Within the rich literature on export performance, at least three theoretical evolutions and related research are worth recalling in order to secure deep understanding of this phenomenon. They come from trade, regional and international business theories, respectively, and are summarized below.

\section{First, trade theory evolving towards a micro approach}

While competitiveness is an illusive concept, its many aspects are measured. Even if we agree that export performance is a good yardstick of productivity and ability to operate in a more (internationally) competitive environment, the level at which we examine export results remains important.

For many years economists relied on a macroeconomic perspective embedded in the traditional trade theory to think about export drivers. Even the new trade theory, which was developed in the 1980s and constitutes the base for 'New' new trade theory, assumed that firms are homogeneous in terms of productivity. This is why our accumulated knowledge about export determinants is mainly built on macroeconomic and sectoral levels. Subsequent theoretical developments showed that macroeconomic perspectives might be insufficient and can often lead to flawed results or, at best, to overlooking important factors and linkages. Antràs et al. (2010) illustrate this problem with the socalled "Spanish paradox". After 2000, the surprisingly good export performance in Spain (relative low loss of the world export share in comparison to France, Italy and Germany) was accompanied by poor international trade price-competitiveness indicators led by real convergence, wage increase, housing bubble and relocation of resources to non-tradable sectors (Correa-López and Doménech, 2012). What seems an inconsistency from a macroeconomic point of view can be explained within a microeconomic approach. Antràs et al. (2010) use firm-level data and indeed find that the "Spanish paradox" might result from composition bias of aggregate figures Altomonte et al. (2012). Analyzing only exporting firms, they indicate that large Spanish companies experienced even lower unit labour cost growth and better export performance than in other countries. More in-depth explanation of the above paradox was given by Correa-López and Doménech (2012), who indicate that many individual investment decisions and actions at companies' level influenced Spanish firms export performance during last years. Those factors relate to improvements of physical and human capital, innovations, reliance on long term financing and presence of foreign ownership (Hanley and Monreal-Pérez, 2012).

We subscribe to the view that competitiveness is produced by aggregation of individual characteristics of firms rather than by the average position of the economy or the sector. In what follows, the microeconomic approach, which is embedded in the 'New' new trade theory, is capable of providing useful insights and explaining many nuances related to trade performance and competitiveness (Melitz, 2003). According to this framework, firms are heterogeneous in terms of 
productivity and only the most efficient ones may export because they can cover fixed costs of trade, and only "the happy few" of them can afford to use the most sophisticated modes of internationalization strategy such as FDI (Mayer and Ottaviano, 2007).

Second, the regional approach providing a complementary perspective to the micro approach - the emergence of 'New' new economic geography

Exports of tradable goods and services exert a profound impact on the domestic economy by generating incomes to be spent in "home markets" and creating home employment (Kemeny and Storper, 2015). While Poland's exports were growing steadily in the recent decades, this growth had a strong regional pattern and exports themselves were spatially concentrated. Indeed, as Ciżkowicz et al. (2013) point out, six out of sixteen voivodships account for around $75 \%$ of total exports. They also investigate and confirm the role of some structural characteristics related to industry-mix, physical and human capital and productivity in affecting regional export performance.

In this paper we argue that regional and microeconomic approaches are complementary and provide additional insights into determinants of exports performance. More specifically, we investigate whether regional disparities can be linked to microeconomic sources of export success. We want to check for example if the firm size and ownership, innovativeness and other features are equally important in structurally different regions.

Theoretical underpinnings for our arguments can be sought for in the recently developing 'New' new economic geography (NNEG). In contrast to the original NEG, focused on macro heterogeneity across locations, NNEG emphasizes links between the macro-heterogeneity and decisions taken at firm and household levels (Ottaviano, 2011). Regional factors not only affect firms' ability to compete, but can also influence their strategy of competing. It may be that the regional environment creates its unique pattern of successfully competing firms, which can in turn produce their own unique externalities raising export performance (Békés and Ottaviano, 2016).

Third, international business factors determining export performance based on resources internal to the firm

Another important layer of the problem emerges from a comprehensive meta-analysis of Zou and Stan (1998), who organized the bulk of earlier studies on enterprise export performance. From there we learn that most of its determinants are directly or indirectly related to industrial structure and business environment as they critically influence strategies followed and decisions taken in enterprises. It means that decisive factors of export performance may lie in company resources. It is in line with International Business and International Entrepreneurship theories based on firms' internal characteristics and resources like learning by doing and learning by interacting experience, intangible and not codified knowledge, strategic management, social capital and network opportunities (Dimitratos et al., 2013).

\section{Testable hypotheses}

The existing theoretical and empirical body of research leads us to formulate several hypotheses, which will be tested in the Polish economy both at aggregate and regional level. We refer to factors indicated by the literature on firm-level data. 


\section{Hypothesis 1: Export performance depends on the company size}

A company's size is found to correlate with its many other features. Most notably, bigger firms tend to outperform smaller ones in terms of productivity, the number of skilled workers and networks, i.e. factors which allow for affording international expansions. The above features may help to overcome (at least to some extent) drawbacks of the environment overregulation, administrative burdens and bear general costs of international activity often called sunk cost. Based on the individual companies EFIGE data for almost 14000 entities from seven EU countries, Navaretti et al. (2012) confirm that there is a set of common features characterizing internationally active companies: exporters are indeed larger, more productive, have a better quality labour force and are often part of a capital group or have a foreign owner and are more innovative and R\&D intensive.

\section{Hypothesis 2: Export performance depends on ownership}

The ownership is seen as a factor potentially explaining a firm's performance, including its internationalization (Kostevc, 2015). Firms managed by their owners tend to overcome the principalagent problems and related costs because owners are more concentrated on long-term horizons and more committed to the company's performance goals. External managers may have different aims and perspective than owners. The ownership issue is usually considered in the context of its structure. Empirical literature has it that more concentrated ownership should lead to higher probability to export and better export performance as well as innovation activities (Kim and Park, 2011; Kostevc, 2015). Institutional owners could also have positive influence on a firm's performance, while negative impact tends to be associated with public ownership.

\section{Hypothesis 3: Export performance depends on the family management role}

Family business literature uses similar arguments to the ownership literature and underlines overcoming the principal-agent problems, succession planning and professionalization of management, such as intergenerational conflicts, leadership and power transfer. Family firms have unique features built on human, social and financial capital which are the subject of resource-based view emphasized by family management literature (e.g. Colli 2013; Wąsowska, 2017). Nevertheless, family involvement may also have a negative influence on the company performance (at least at some stages of development) because of the competences and openness constraints, too conservative approach, favouring family employment, etc. ${ }^{3}$

\section{Hypothesis 4: Export performance depends on foreign investors' involvement}

Special attention in the literature is paid to the role of foreign ownership, which is seen as a positive driver of internationalization (Navaretti, 2010). Foreign investment presence should give access to international production networks, foreign markets and the so-called spillover effects, that is the spread of knowledge and innovation in the local environment through links with foreign entities (Gorodnichenko et al., 2014). However, research also suggests that positive effects of FDI presence are conditioned by such factors as investors' motivation to enter a market, the structure and type of

\footnotetext{
${ }^{3}$ More on family companies and internationalisation see: Wach (2014), Daszkiewicz and Wach (2014).
} 
FDI (including the level of technological advancement and business), entry modes, etc. (Crespo and Fortuna, 2006).

\section{Hypothesis 5: Export performance depends on innovations}

Research generally confirms the relationship between innovation and exports, although without clearly defining the direction of causality: whether innovation contributes to the growth of exports (self-selection hypothesis) or exports increase innovation (learning-by-exporting). The self-selection hypothesis is more often confirmed as opposed to the learning-by-exporting hypothesis. Usually the impact of innovation, especially product innovation, is indicated as a driver for export (Damijan et al., 2014). In other words, a company has to be innovative first in order to be ready to effectively compete in international markets. Increasing innovation thanks to export activity is less common but positive effects of exports on productivity and innovativeness of domestic firms can also be observed, especially within the Global Value Chains (Damijan et al., 2014; Hagemejer, 2015; Rodíl et al., 2016).

\section{A macro portrait of Polish regions}

Regional disparities in Poland are amongst starkest in all EU member states. In 2014 GDP per capita in the richest Mazowieckie Voivodship (NUTS-2 region in Poland) was 2.29 higher than in the poorest Lubelskie. ${ }^{4}$ This ratio was thus higher than in Spain (1.98) and only marginally lower than in Italy (2.46). Just like in these two reference countries, income disparities merely reflect the extent of structural divergence, which influences all areas of economic dynamics. In the case of Poland sharp structural differences are observed especially between Western and Eastern Poland to the extent that "Poland A" and "Poland B" terms have been coined and settled to label these two geographical areas. The differences are most striking in the role (and the extent of backwardness) of agricultural sector, state of infrastructure, business sector structure (e.g. importance of family-run businesses, intensity of competition) as well as the role and size of economic base. On top of this, there is also the proximity-to-foreign-markets issue with eastern regions located on the EU border with Belarus, Ukraine and Russia and thus more isolated than western regions, sharing borders with Germany, Czechia or the Baltic sea with its ports. Even this quick glance indicates that region-specific factors might play a prominent role in export performance of firms in Poland.

Regional economic research on Poland usually acknowledges the importance of structural differences, which in turn trigger diverse regional economic dynamics (Cieślik, 2005; Chidlow et al., 2009; Gajewski, 2015 and 2016). Most of these differences have deep historical roots, dating back to the period of partitions, between 1792 and 1918, when divided between Russia, Prussia and Habsburg Austria, the country was shaped by three distinct social and economic systems and policies. While the division between western "Poland A" and eastern "Poland B" is a multilayered one, the focus of this paper is on export performance, so a natural staring point is the comparison of regional openness to international trade.

\footnotetext{
${ }^{4}$ Data on regional GDP per capita extracted from Eurostat on 12.05.2016.
} 
Poland has been consistently following a trend of raising its exports to GDP share in recent years and this is clearly visible at the regional level (see Figure 1). At the same time, voivodships remain polarized in terms of their openness. While exports/GDP exceeds $40 \%$ in most western parts, which have much better access to EU markets, eastern voivodships are still rather closed, with export shares in the range between 15 and $20 \%$.

Figure 1. Exports per employee in Polish voivodships

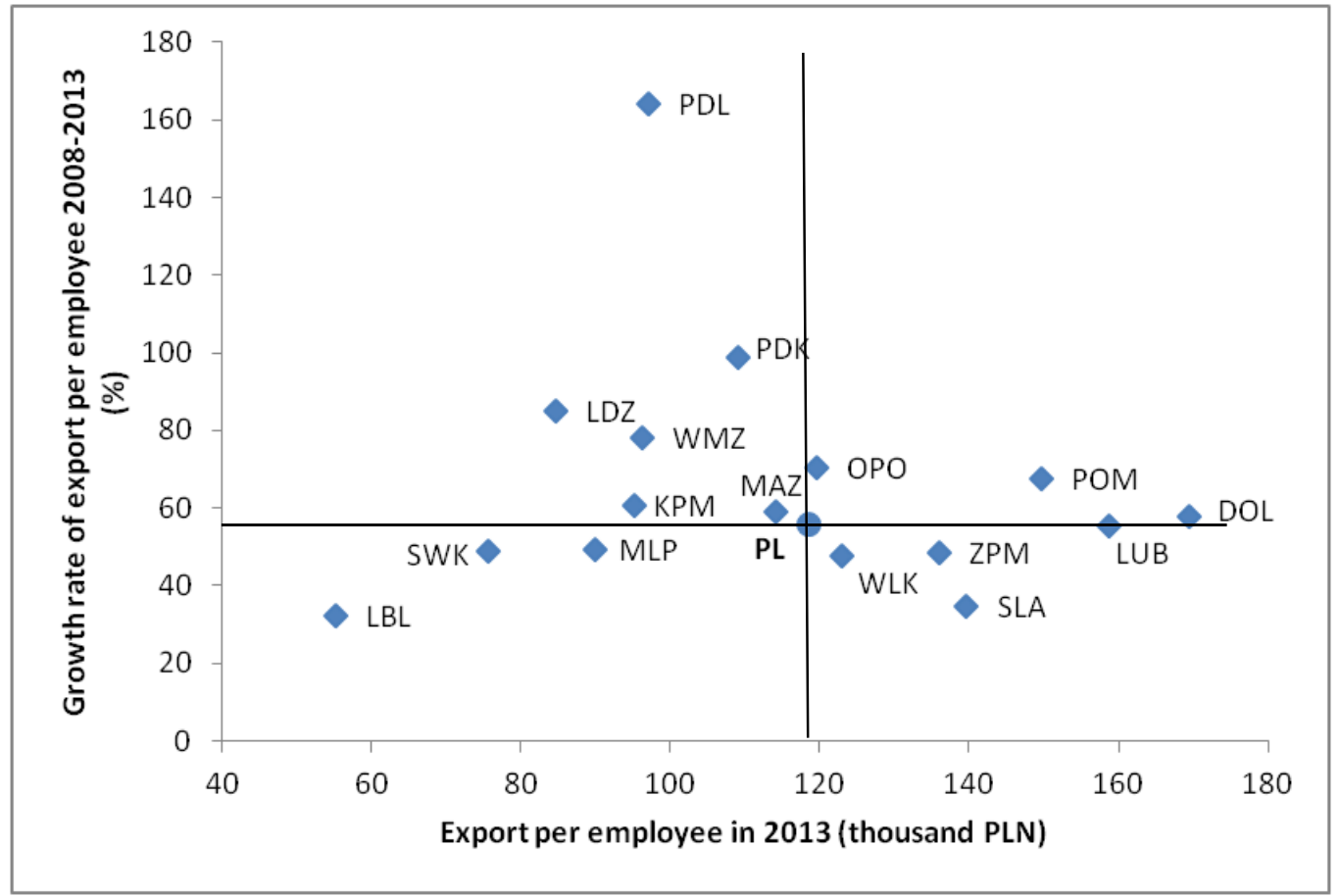

Notes: MAZ - Mazowieckie, ZPM - Zachodniopomorskie, POM - Pomorskie, DOL - Dolnośląskie, WLK Wielkopolskie, LUB - Lubuskie, MLP - Małopolskie, SLA - Śląskie, OPO - Opolskie, LDZ - Łódzkie, KPM Kujawsko-Pomorskie, SWK - Świętokrzyskie, WMZ - Warmińsko-Mazurskie, PDL - Podlaskie, LBL - Lubelskie, PDK - Podkarpackie.

Source: Umiński et al. (2015) and own calculations based on Eurostat data.

Locational factors, combined with the deeply rooted structural differences and conserved by deficiencies in infrastructure, produced quite distinct regional business sector environments. Figure 2 plots the number of firms per capita (relative to Poland's average) and gross flow ratio of firms (number of new firms + number of closed firms to total number of existing firms). The correlation between these two variables is very high and clear regional polarization stands out. The saturation of firms in Mazowieckie is around 30\% higher than in Poland on average, which can be easily attributed to the presence of Warsaw agglomeration. The above-average numbers of firms per inhabitant (and gross flows of firms at the same time) are found in western voivodships: Zachodniopomorskie, Pomorskie, Dolnośląskie and Wielkopolskie. Eastern belt voivodships on the other hand have the number of firms per inhabitant that is $20-30 \%$ lower than average and also the lowest flow ratios of firms. 
Figure 2. Regional business demographics indices in Poland in 2014

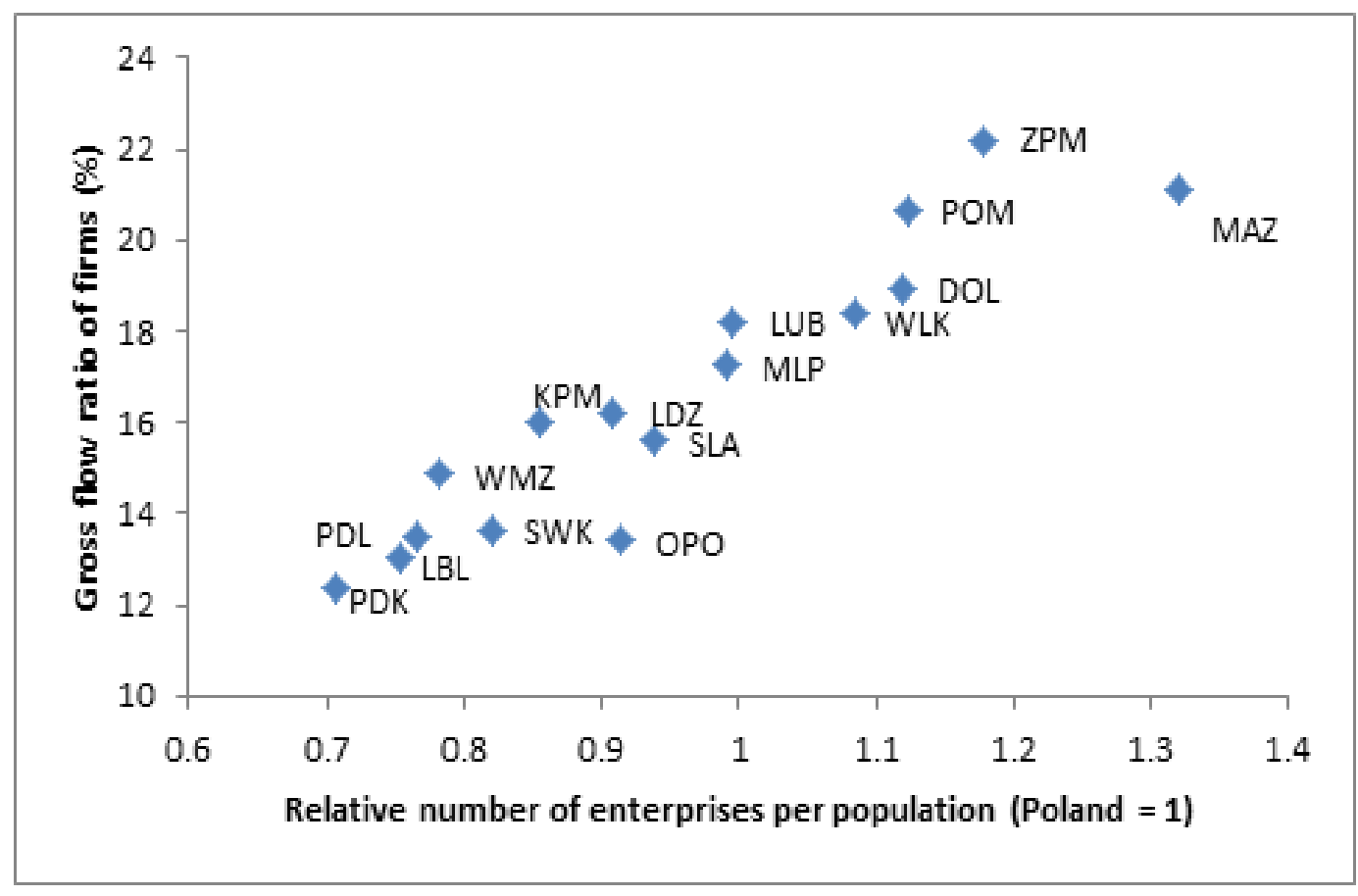

Notes: gross flow ratio is defined as the sum of newly created firms and closed firms, divided by total number of existing firms; MAZ - Mazowieckie, ZPM - Zachodniopomorskie, POM - Pomorskie, DOL Dolnośląskie, WLK - Wielkopolskie, LUB - Lubuskie, MLP - Małopolskie, SLA - Śląskie, OPO Opolskie, LDZ - Łódzkie, KPM - Kujawsko-Pomorskie, SWK - Świętokrzyskie, WMZ - WarmińskoMazurskie, PDL - Podlaskie, LBL - Lubelskie, PDK - Podkarpackie.

While competitive environments illustrated in Figure 2 reflect structural differences across regions, not all business environment features submit to these divisions. One example is specialization patterns (see Table A1 in Annex). Voivodships have their specializations, which however cannot be easily explained by their location in western or eastern Poland. True, the mining industries as a specialization were rooted in Śląskie and Dolnośląskie, two voivodships in the south-western part of the country but otherwise the traditional East-West division does not play a crucial role here. For example, the wood and furniture industries are generally well developed and create economic base in the northern part of Poland, including Zachodniopomorskie and Wielkopolskie in the west as well as Warmińsko-Mazurskie and Podlaskie in the East. More and more often local and regional specializations are developed and strengthened in cooperation with public authorities and with their financial assistance and implemented in the form of carefully planned strategies. Whether specialization itself creates more opportunities than threats remains an open issue as "the devil is in the details" (Dissart, 2003; Kemeny and Storper, 2015). An illustration of materialized threats from specialization is provided by the central Łódzkie Voivodship, which has been struggling for many years to escape its specialization in the declining textile industries that still remains a drag on growth. Śląskie is yet another example of a region highly specialized in declining (or at least non-prospective) mining industries. Overall, we subscribe to the view that a diversified industrial structure provides better conditions for smooth, long-run development, although at an early stage specialization might be an efficient strategy to build regional economic base and stimulate growth. At a later stage, diversification may be a result of developing multiple specializations and/or growth of non-base 
industries. In this context, the higher Krugman and IIP specialization indices in eastern viovodships confirm the conventional view that these regions are at earlier stages in the process of economic base building. This makes them (at least temporarily) more vulnerable to shocks but allows speeding up convergence in good times. On the other hand, vulnerability can be at least partially alleviated if regions specialize in growing, "new” industries that tend to be more flexible and provide some degree of resilience (Martin and Sunley, 2015).

Another aspect where the East-West division generally seems fuzzy is the enterprise innovative activity, at least as long as manufacturing is concerned. Contrary to the conventional image of backward East and (relatively) innovative West, most up to date research shows that firms in eastern regions are at least equally aware about the necessity to introduce product and process innovations as their western counterparts. Indeed, GUS (2015) shows that the share of innovative manufacturing firms in Podlaskie, Lubelskie and Podkarpackie is higher than average in Poland. Moreover, the share of firms there where implementing new, "significantly improved" products is a top priority is high and in Podlaskie it was highest in Poland in the 2011-2012 survey (GUS, 2015). We think that it is interesting to investigate whether innovative activity has a contemporaneous link with export performance and whether this association differs in strength and nature between eastern and western firms in Poland.

To summarize our brief macro-portrait, it is legitimate to state that Poland's regional economic landscape is diverse but dynamic. While export per employee in 2013 may, to a large extent, measure "capabilities" to export, the rate of export growth illustrates changes which took place between 2008 and 2013 at the regional level. Taking such a perspective allows us to conclude that whereas some long-lasting historical divergences are petrified, due to the West's unquestionable advantage over the East in terms of level of development, capital stock, etc., there are also signs of catching-up and gap-bridging. Regional export performance is likely to be influenced by this blend of factors.

\section{Data and empirical approach}

\subsection{The survey}

Most researchers must be aware of the relevance of micro-perspective in investigating export performance, since firms are heterogeneous in nature and reveal different types of investment decisions and reaction behaviours. Yet turning to this perspective in empirical studies often proves unfeasible due deficiencies of usable data, comparable across countries.

In an attempt to overcome this major obstacle, the EFIGE (European Firms In Global Economy, www.efige.org) research project, led by the Bruegel think tank, was launched and completed. It produced a unique firm-level dataset, covering a sample of almost 15000 firms in seven EU countries. Data was collected in 2010 and it refers mostly to 2008, but in some dimensions also to the 2007-2009 period (Altomonte and Aquilante, 2012). How much this database was needed is testified by the number of research publications which draw from it, despite its freshness (see e.g. Altomonte et al., 2015; Cingano and Pinotti, 2016; Cosci et al., 2016).

The EFIGE project was an inspiration for establishing a similar database in Poland within the project The euro introduction and competitiveness of the Polish enterprises conducted at the University of 
Warsaw and financed by the National Science Centre. Thanks to the Memorandum of Understanding between the Bruegel think-thank and the University of Warsaw, the survey was based on the questionnaire used in the unique EFIGE survey. Manufacturing firms with more than 10 employees in Poland were surveyed at the end of 2014 and in 2015 and questioned about their activity and decisions in 2013 and (where relevant) the 2010-2013 period. Data was collected via the CATI method (Computer Assisted Telephone Interview). We used mixed purposive and quota sampling methods in order to find the balance between sample representativeness, comparability to EFIGE data and research aims of the project.

Our compiled database consists of two parts. The first part replicates 50 questions from the EFIGE questionnaire, choosing those which are "structural" in nature. They cover six areas of company characteristics: 1. Structure of firms (company ownership, domestic and foreign control, management), 2. Workforce (skills, type of contracts, domestic vs. migrant workers, training), 3. Investment, technological innovation, R\&D (and related financing), 4. Export and internationalization processes, 5. Market structure and competition, 6. Financial structure and bank-firm relationship. This subsample is representative in terms of industrial structure based on NACE 2 classification and at NUTS 2 regional level, but not in terms of size. Medium (50-249 employees) and large (more than 250) companies were oversampled. The second part is an original extension to include respondents' opinions on the consequences of the euro adoption in Poland and as such it is not used in this paper.

Our examined database covers more than 730 Polish export enterprises from the manufacturing sector with more than ten employees. The sample amounts to $3.3 \%$ of the total population of 22000 (as of 2013) manufacturing industrial companies with more than 10 employees.

\subsection{Empirical strategy}

\section{i. Cross-sectional model}

In order to unveil factors of success in exporting manufacturing companies, we employ a simple linear cross-sectional model:

$$
\operatorname{exs}_{i}=\beta_{0}+\beta_{1} \mathbf{z}_{i}+\varepsilon_{i}
$$

Where $\operatorname{exs}_{i}$ is the export share in total revenues (in \%) of $i$-th enterprise and $\mathbf{z}_{i}$ is a vector of explanatory variables:

$\mathbf{z}_{i}=\left[\begin{array}{lllllllll}\operatorname{bir}_{i} & \text { noc }_{i} & \text { own }_{i} & \text { fam }_{i} & \text { med }_{i} & \text { big }_{i} & \text { fgn }_{i} & \text { ipd }_{i} & \boldsymbol{i p c _ { i }}\end{array}\right]^{\mathrm{T}}$

bir - year of birth

noc - number of declared non-cost factors of success (quality of products, diversified product offer, brand recognition, developed distribution chain, post-sales services, other); noc $\in\{1,2 \ldots, 6\}$

own - a firm run by owner (binary variable)

fam - a firm controlled by family (binary variable) 
med - a firm has revenue between 2 and 10 million euro (binary variable)

big - a firm has revenue over 10 million euro (binary variable)

$f g n-a$ firm is controlled by foreign entity/capital group (binary variable)

ipd - a firm introduced one or more innovative products between 2010 and 2013 (binary variable)

ipc - a firm introduced one or more innovative processes between 2010 and 2013 (binary variable)

The number of enterprises in individual voivodships in our data set is usually insufficient to conduct independent regressions and draw meaningful inferences. A simple alternative in this situation is to aggregate all firms in a single cross-sectional model and control for cross-regional disparities with regional dummies. This approach however imposes a strong assumption that slope coefficients across all regions are the same and thus throws away important information. ${ }^{5}$

\section{ii. Construction of ad-hoc macro-regions}

Rather than aggregating firms across all regions, we prefer to construct a small number of relatively homogenous ad-hoc macro-regions to obtain more flexible specifications, leaving us the opportunity to estimate all slope coefficients separately. Since we are mostly interested in East-West disparities, we start with "flagship" regions representing eastern and western Poland, add one potential candidate region, re-run our cross-sectional model on an enlarged sample and perform tests of heteroscedasticity, while also checking statistical significance of regional dummies within the group. If heteroskedasticity is not detected and regional dummies appear insignificant, the next candidate region is added and the new sample is tested in the same way. Following this procedure leads us to construct the two following macroregions ${ }^{6}$ :

- East, consisting of: Lubelskie, Podkarpackie, Podlaskie, Warmińsko-Mazurskie and Świętokrzyskie Voivodships, and

- West, composed of: Dolnośląskie, Lubuskie, Opolskie, Pomorskie, Wielkopolskie, Zachodniopomorskie and Śląskie Voivodships.

It should be acknowledged on the side note that the composition of the East is identical to the official government definition of Eastern Poland created for the purposes of regional policy, including the construction of area development strategies (see e.g. MliR, 2015). Compared to the definition of Western Poland there, our West contains two additional voivodships: Pomorskie and Śląskie.

The remaining four voivodships (Mazowieckie, Łódzkie, Kujawsko-Pomorskie and Małopolskie) form the central belt separating the West from the East but do not fit any of these groups. Mazowieckie is structurally distinct because of comprising both large, underdeveloped agricultural lands on the one hand and the administrative and financial capital city of Warsaw - on the other. Very often this voivodship appears to be an outlier and is frequently disregarded in regional analyses (e.g. Gajewski, 2007; Tokarski, 2008; Nakamura and Taguchi, 2011). Since all attempts to create an additional group

\footnotetext{
${ }^{5}$ Additionally, the model specified in this way suffers from variance heteroskedasticity, which adds to our supposition of cross-regional heterogeneity (results not reported to save space - available upon request). ${ }^{6}$ The composition of both macroregions was found robust to several orders of adding voivodships.
} 
comprising two or more of these four regions turned unsuccessful, we decided to exclude them from our empirical exercises and only focus on the West and the East.

\subsection{Descriptive statistics}

Tables 1 and 2 present descriptive statistics of our sample, separately for firms located in the West and the East. Altogether we have 446 firms in the West and 153 firms in the East, but some observations are missing. As appears from Table 1, firms in the East are on average marginally older. A typical manufacturing exporter in the West receives a somewhat higher proportion of its revenues from exports, although relies on non-cost competitiveness to a slightly lesser extent. Admittedly, means in all three categories are close across the two groups and the differences between them turn insignificant according to one-sided $t$-tests.

Table 1. Descriptive statistics of interval (continuous) variables

\begin{tabular}{|c|c|c|c|c|c|c|c|c|c|c|c|c|}
\hline Variable & Variable & \multicolumn{5}{|c|}{ WEST $(n=446)$} & \multicolumn{5}{|c|}{ EAST $(n=156)$} & t-test \\
\hline & & Obs & Mean & S.D. & Min & Max & Obs & Mean & S.D. & Min & Max & \\
\hline $\begin{array}{l}\text { Share of exports } \\
\text { in total revenue } \\
\text { (\%) }\end{array}$ & exs & 387 & 36.5 & 28.1 & 1 & 100 & 132 & 35.7 & 24.3 & 1 & 100 & 0.39 \\
\hline Year of birth & bir & 439 & 1994 & 14.1 & 1897 & 2014 & 155 & 1993 & 15.7 & 1926 & 2014 & 0.29 \\
\hline $\begin{array}{l}\text { Number of non- } \\
\text { cost factors of } \\
\text { success }\end{array}$ & noc & 443 & 1.93 & 1.36 & 0 & 6 & 155 & 2.05 & 1.2 & 0 & 6 & 0.19 \\
\hline
\end{tabular}

More differences across our subsamples can be observed in terms of our binary variables. Indeed, while most firms in our sample are run by the owner and/or controlled by a family, both shares are somewhat higher in the West (see Table 2). Small firms in terms of revenue (i.e. below 2 million euros annually) generally dominate in our sample, but in the East we have a noticeably higher proportion of the biggest firms, with revenues exceeding 10 million euros. ${ }^{7}$ As expected, we observe a higher foreign penetration in the West, although the difference with respect to the East is not striking. Finally, most of the firms claim to have implemented innovations of some kind in the recent past. Innovative products were introduced more often than process innovations and both were more frequent in the West.

\footnotetext{
${ }^{7}$ This picture seems to be little surprising, but a similar situation occurs e.g. in East and West German manufacturing firms, examined in terms of export activity during the great trade collapse in 2008 and 2009. Concentration of the largest East German manufacturing exporters was found to be almost two times higher than in West Germany (Wagner, 2012).
} 
Table 2. Summary statistics of binary variables

\begin{tabular}{l|c|rrrr}
\hline Variable description & Variable & \multicolumn{3}{|c}{ WEST $(n=446)$} & \multicolumn{2}{c}{ EAST $(n=156)$} \\
\cline { 3 - 7 } & name & Freq. & Share & Freq. & Share \\
Firms run by owner & own & 328 & 75.23 & 98 & 64.05 \\
Firms controlled by family & fam & 278 & 63.76 & 78 & 50.98 \\
Firms with revenue 2 - 10 million euro & med & 80 & 18.35 & 31 & 20.26 \\
Firms with revenue over 10 million euro & big & 47 & 10.78 & 25 & 16.34 \\
Firms controlled by foreign & fgn & 50 & 11.47 & 16 & 10.46 \\
entity/capital group & & & & & \\
Firms which introduced innovative & ipd & 279 & 63.99 & 69 & 47.23 \\
products between 2010 and 2013 & & & & & \\
Firms which introduced innovative & ipc & 193 & 44.27 & 43 & 29.45 \\
processes between 2010 and 2013 & & & & & \\
\hline
\end{tabular}

Correlation coefficients between variables in our sample do not appear strong (Table 3). With the exception of a moderately strong relationship between the number of firms run by owner and controlled by family (families are often the main owners), all coefficients are in the low .10s or smaller and often insignificant. The export share seems to be positively associated with innovative activity (notably product innovations), size and foreign control over an enterprise.

The correlation analysis offers more possible interesting outcomes which can improve our understanding of enterprise performance in the sample. For example, ipc is significantly and negatively correlated with fam, which indicates lower propensity of family-controlled firms to introduce process innovations. On the other hand, the positive correlation between ipc and ipd suggests that in many cases both types of innovations are complementary rather than substitutes or that innovative firms often have a more general nature. Finally, we acknowledge a positive and significant correlation between noc and both variables capturing innovative attitude. Enterprises which implement product and process innovations are more successful in competing on a non-price basis, which can be perceived as more flexibility in terms of its margin.

Table 3. Pearson cross-correlation coefficients - full sample

\begin{tabular}{l|cccccccccc}
\hline & exs & own & fam & bir & med & big & fgn & ipd & ipc & noc \\
\hline exs & 1 & & & & & & & & & \\
own & -0.01 & 1 & & & & & & & & \\
fam & -0.04 & $0.64^{*}$ & 1 & & & & & & & \\
bir & -0.05 & $0.11^{*}$ & 0.09 & 1 & & & & & & \\
med & $0.10^{*}$ & $0.14^{*}$ & $0.12^{*}$ & -0.01 & 1 & & & & & \\
big & $0.13^{*}$ & 0.05 & $0.09 *$ & -0.10 & $-0.10^{*}$ & 1 & & & & \\
fgn & $0.15^{*}$ & -0.01 & -0.04 & 0.05 & $0.11^{*}$ & $0.12^{*}$ & 1 & & & \\
ipd & $0.14^{*}$ & -0.06 & -0.08 & -0.04 & 0.07 & 0.09 & 0.04 & 1 & & \\
ipc & 0.10 & -0.09 & $-0.11^{*}$ & 0.01 & 0.05 & 0.06 & 0.08 & $0.13^{*}$ & 1 & \\
noc & $0.14^{*}$ & -0.01 & 0.07 & -0.02 & $0.13^{*}$ & 0.05 & 0.01 & $0.12^{*}$ & $0.14^{*}$ & 1 \\
\hline
\end{tabular}

Notes: Pairwise correlation coefficients computed with Bonferroni adjustment; ${ }^{*}$ denotes significance at $5 \%$ level. 


\section{Results}

The model is estimated on a full sample as well as in West and East subsamples separately. Even though we construct our macroregions in the way which ensures that the constant variance hypothesis is not rejected, the Huber-White sandwich estimator is employed to ensure unbiased standard errors. As a robustness check, estimations are also performed with OLS, while individual region (voivodship) cross-sectional fixed effects are controlled for. Results are presented in Table 4.

Table 4. Estimation results

\begin{tabular}{|c|c|c|c|c|c|c|}
\hline \multirow[t]{2}{*}{ Variable } & \multicolumn{2}{|c|}{ Full sample } & \multicolumn{2}{|c|}{ West } & \multicolumn{2}{|c|}{ East } \\
\hline & $\mathrm{H}-\mathrm{W}$ & FE & $\mathrm{H}-\mathrm{W}$ & $\mathrm{FE}$ & $\mathrm{H}-\mathrm{W}$ & $\mathrm{FE}$ \\
\hline \multirow[t]{2}{*}{ own } & $4.59 * *$ & $4.17^{*}$ & $5.62 *$ & 5.06 & $11.79 * * *$ & $11.38 * *$ \\
\hline & $(2.11)$ & (2.29) & (3.23) & (3.65) & $(4.73)$ & $(4.92)$ \\
\hline \multirow[t]{2}{*}{ fam*bir } & -0.48 & -0.56 & -0.88 & -1.00 & $-4.97 * *$ & $-4.80 * *$ \\
\hline & (1.01) & (1.04) & $(0.55)$ & (1.67) & $(2.28)$ & $(2.36)$ \\
\hline \multirow[t]{2}{*}{ med } & $7.35 * * *$ & $7.16^{* * *}$ & $7.53^{*}$ & $7.53^{* *}$ & 0.22 & -0.34 \\
\hline & (2.69) & (2.59) & $(4.00)$ & $(3.71)$ & (5.58) & $(5.74)$ \\
\hline \multirow[t]{2}{*}{ big } & $9.60 * * *$ & $9.57 * * *$ & $10.74^{* *}$ & $10.64^{* *}$ & 1.33 & 1.07 \\
\hline & $(2.88)$ & $(2.77)$ & $(4.54)$ & $(4.58)$ & (5.87) & (5.70) \\
\hline \multirow[t]{2}{*}{ fgn } & $11.35^{* * *}$ & $11.21^{* * *}$ & $10.33^{* *}$ & $10.56^{* *}$ & 11.65 & 11.38 \\
\hline & (3.14) & $(2.96)$ & $(4.52)$ & $(4.58)$ & $(8.22)$ & (6.93) \\
\hline \multirow[t]{2}{*}{ ipd } & $6.00 * * *$ & $6.71^{* * *}$ & $5.78 *$ & $5.83^{*}$ & $8.71^{* *}$ & $8.53^{* *}$ \\
\hline & $(2.00)$ & $(2.04)$ & (3.16) & (3.19) & $(4.26)$ & $(4.31)$ \\
\hline \multirow[t]{2}{*}{$i p c$} & 2.24 & 2.07 & 4.58 & 4.70 & -0.98 & -0.81 \\
\hline & (1.89) & (1.93) & (3.07) & (3.10) & $(4.61)$ & $(4.52)$ \\
\hline \multirow[t]{2}{*}{ noc } & $1.77^{* * *}$ & $1.73^{* *}$ & 0.70 & 0.87 & $3.27^{* *}$ & $3.38^{*}$ \\
\hline & $(0.62)$ & $(0.69)$ & $(0.95)$ & (1.09) & $(1.74)$ & $(1.84)$ \\
\hline \multirow[t]{2}{*}{ constant } & $19.33^{* * *}$ & $19.75^{* * *}$ & $21.77^{* * *}$ & $20.60 * * *$ & $20.09 * * *$ & $24.13 * * *$ \\
\hline & $(2.64)$ & $(4.47)$ & $(4.14)$ & $(5.09)$ & $(7.42)$ & $(8.07)$ \\
\hline $\mathrm{R}^{2}$ (adjusted) & 0.08 & 0.08 & 0.07 & 0.05 & 0.12 & 0.05 \\
\hline$F$ test ( $p$-val) & 0.00 & 0.00 & 0.00 & 0.00 & 0.03 & 0.11 \\
\hline Log-likelihood & -3412 & & -1778 & & -594 & \\
\hline $\mathrm{N}$ & 736 & 736 & 377 & 377 & 131 & 131 \\
\hline
\end{tabular}

Notes: standard errors in parentheses. $*, * *, * * *$ denotes significance at $10 \%, 5 \%$ and $1 \%$ respectively.

Our empirical results offer some appealing conclusions. Let us start with discussing results obtained in full sample, the bulk of which is admittedly in line with conclusions from previous studies. Most notably, we see an important and positive role of the firm size and foreign ownership (Navaretti, 2012; Cieślik et al., 2015). Moving further, there is evidence of a positive role of product innovations, but no direct role of process innovations. The same conclusions are arrived at by e.g. Cassiman and Golovko (2007), Fasil (2009) and Becker and Egger (2013). Indeed, product innovations are typically found to carry a better cost-benefit ratio of a firm's R\&D expenditure (Fasil, 2009). Finally, increasing the number of non-cost advantages is found to generally positively affect export performance. The purpose of this variable was to capture reliance on non-price competition in foreign markets, which 
plays a crucial role for export performance in the New Trade Theory models (e.g. Athanasoglou and Bardaka, 2010). An important role of non-cost factors, such as quality and diversity of traded goods, for driving exports in CEE countries was also recently confirmed empirically by Benkovskis and Worz (2012). ${ }^{8}$ There is also some empirical evidence, mentioned earlier, that firms with more concentrated ownership and run by the owner can be more effective in expanding to foreign markets (Kim and Park, 2011; Kostevc, 2015). This general picture, consistent with existing empirical evidence, breaks down when East and West subsamples are extracted.

The subsequent columns indicate that having owner as a chief executive is very important for exporting firms in the East and also more experienced (deeply rooted) family firms tend to perform better there, but both factors turn out insignificant, or at most weakly significant in the West. One of the explanations might be that ownership and family ties in business are important factors when operating in a challenging environment, where - in line with family business literature - they can be irreplaceable carriers of knowledge and social and financial capital. As such, they can also serve to break barriers to starting the export activity. These results, although new, generally comply with the common view on the structural features of Poland " $\mathrm{A}$ " and " $\mathrm{B}$ ". But intuitive results end here and the remaining ones tell a rather new story about Poland's regional development.

While we are able to confirm the usual finding of the role of size and foreign ownership in the West, none of these factors seem to play a role in the East. What we find there instead is a substantially more important role of creating innovative products and developing non-cost related sources of advantage. Interpretation of these intriguing findings calls for referring to theories of regional development. Classical regional growth models emphasize the role of physical capital accumulation, the production factor governed by the law of diminishing returns. These models predict convergence as capital flows to less developed regions to rip off higher returns. A common explanation for persistent or even widening cross-regional disparities is that increasing rather than decreasing returns prevail in industries based on some non-traditional production factors, i.e. technology, human capital or social capital (see e.g. Guastella and Timpano, 2016). These industries are assumed to dominate in more developed regions and are not achievable for less developed ones. Consequently, the former regions can still develop, while the latter are caught in a kind of a "middle income trap". To overcome it, a region must somehow create a critical mass of innovation or accommodate a niche to start exploiting increasing returns.

Using the above reasoning to explain stages of regional development, we arrive at the outcome close to the one offered by the Clark-Fisher theory (Fisher, 1939; Clark, 1940). A region is first dominated by agriculture. With time, physical capital is accumulated and industrial base is developed, which leads to higher productivity and incomes. In the third stage, a region becomes dominated by highly specialized activities based on increasing returns, but its occurrence is not automatic. Whether it is achieved depends on the region's ability to breach the critical point overcome the development trap.

\footnotetext{
${ }^{8}$ Non-price competitiveness (understood as an improving quality and diversity of traded goods) seems to be important driver of export increase among Central Eastern European countries (Benkovskis and Wörz, 2012). Interesting view on complementarity between price competitiveness factor (exchange rate level) and non-price factor (innovation activity) is offered by Brzozowski and Tchorek (2016). Based on the research on Polish firms they claim that innovative companies use technology to gain competitive advantage but their success and innovation activity also hinge upon weak exchange rate.
} 
While Poland's West seems to be well-grounded in the second stage and also rely heavily on foreign capital as a source of internationalization, our results suggest that a group of innovative, family-run enterprises in the East (the region still largely rooted in agriculture-dominant first stage) might have started to develop economic base in third-stage industries, where the contribution of product innovations and non-price factors are indispensable to success. This being said, we must emphasize that it is too early to claim that Poland's East is now skipping two stages and shifts from agriculturedominant straight to being an innovation leader. But it confirms that there is a group of family innovative companies, able to compete on international markets. As a word of caution, we must also bear in mind the generally lower export activity of enterprises in this macroregion.

\section{Conclusions and discussion}

With the awareness of many limitations, we acknowledge that the ability of firms to compete in international markets is deeply rooted in their individual characteristics, the regional environment in which they operate and also in some common-for-all country-wide settings.

This paper removes the country-wide layer, while integrating firm-level data with region-specific structural features to investigate the role of microeconomic factors in structurally dissimilar regions: Western Poland " $\mathrm{A}$ " - traditionally seen as more developed, and Eastern "Poland B" - commonly perceived as lagging-behind. From the pool of voivodships we create two ad-hoc macroregions which correspond to this division, and arrive at some interesting results. Most notably, while the conventional findings of the role of size, foreign ownership, innovation and family-related factors for export performance are confirmed at the aggregate level, we show how relevant it is to account for intra-national spatial heterogeneity, in addition to firm heterogeneity.

Our results shed new light on the pattern of regional development in Poland. The development of the West seems to follow the usual path, the macroregion currently being at the stage of heavy reliance on foreign capital in building its economic base and also drawing from economies of scale. In contrast, exporters in the East (admittedly fewer in number) are found to rely on innovation activity, non-price competitiveness and family experience as sources of success in international markets, while the company size does not seem to play any role. It may mean that these companies successfully accommodate some niches and have enough internal resources to be internationalized. While we could only detect the beginning of the process, sustaining it might eventually earn the East solid grounds for its long-run development, by rooting it in industries governed by increasing returns.

We believe that some policy-related implications can be derived from our exercise. Firstly, the only decisive factor which appeared to be a statistically significant exports driver in both East and West was the firm's innovation activity. Local policy makers may thus draw lessons for improving social capital institutions and innovation capabilities which constitute important element of innovation "ecosystems".

Secondly, aiming at increasing presence in international markets, policy makers and business managers should think about defining right paths and instruments for transformation of familyowned competitive companies, which are still small or very small in international terms, to secure their position as true hidden champions. 
Thirdly, the results deserve attention, and possibly additional research, from regional policymakers in terms of EU funds distribution and regional innovative specialization policies. Our findings suggest that the export performance premium for innovativeness and non-cost factors reliance is higher in the East than in the West. If so, it might mean that the effects of innovation policy could be more profound efficient in less developed areas. Admittedly, this result would be at odds with the conventional assumption of increasing returns to innovation and the research should go into the direction of exploring variables and mechanisms that disturb these returns.

While our empirical exercise produced interesting results, some issues remain. Regrettably, our dataset did not allow for separate investigations of export performance drivers in individual voivodships. Furthermore, we now believe that there could be additional value added from a more detailed breakdown of innovation activity in firms. We put addressing both these issues on a list to enable even deeper insights into international trade patterns at the firm level in Poland.

There are also more general future research paths to be suggested. First, auxiliary interviews with managers, performed during the data collection, point to a possibly diverse understanding of innovativeness itself, especially process innovations. It might be that the perception of what constitutes an innovation is different e.g. in family-run businesses as opposed to foreign capital firms or in enterprises belonging to separate size classes. It would be worth checking whether these differences are significant and whether (controlling for firm-specific perceptions) some regional patterns remain. Exploring this path would certainly call for an inter-disciplinary approach, accounting for sociological input.

Another intriguing challenge could be to investigate links between business environment features and regional resilience, using micro-data. Despite increasing trade links and globalization before the crisis, competitiveness of countries was based on local/regional advantages. After the great trade collapse in 2008/2009 and fragile recovery thereafter accompanied by structural weaknesses, local resources and capabilities will be more decisive in creating sustainable growth of regions and countries.

\section{References}

Altomonte C., Aquilante T., Békés G., Ottaviano G.I.P (2013). "Internationalization and innovation of firms: evidence and policy", Economic Policy 28.76: 663-700.

Altomonte C., Aquilante T., Ottaviano G.I. P (2012), "The Trigger of Competitiveness - The EFIGE Cross Country Report", Bruegel Blueprint Series, Vol XVII.

Altomonte C., Barattieri A., Basu S. (2015) "Average-cost pricing: Some evidence and implications," European Economic Review, 79: 281-296, 2015.

Altomonte, C., Aquilante, T. (2012). The EU-EFIGE/Bruegel-UniCredit Dataset, Bruegel, Working Paper 2012/13.

Antràs, P, Segura-Cayuela R., Rodríguez-Rodríguez D. (2010), "Firms in International Trade (with an Application to Spain)", SERIEs Invited Lecture at the XXXV Simposium of the Spanish Economic Society.

Athanasoglou, P. Bardaka I. C., (2010). "New trade theory, non-price competitiveness and export performance," Economic Modelling, Elsevier, vol. 27(1), pages 217-228. 
Becker S., Egger P., (2013). "Endogenous product versus process innovation and a firm's propensity to export," Empirical Economics, Springer, vol. 44(1), pages 329-354.

Békés G. Ottaviano G. I.P. (2016). "Micro-founded measurement of regional competitiveness in Europe" in (Altomonte C., Békés G. eds.) "Measuring competitiveness in Europe: resource allocation, granularity and trade" EDITORS BRUEGEL BLUEPRINT SERIES, Volume XVIV.

Békés G.,G. I.P. Ottaviano (2016). "Micro-founded measurement of regional competitiveness in Europe", Bruegel Bluprint Series \#24, Bruegel, Brussels, January, 2016.

Benkovskis, K., \& Wörz, J. (2013). "Non-price competitiveness of exports from emerging countries". Working paper series \#1612. European Central Bank (November).

Boscá J. E., Doménech R., Ferri J., Varela J. (2011), "The Spanish Economy: A General Equilibrium Perspective", Palgrave MacMillan.

Brzozowski M. Tchorek G. (2016), "Exchange Rate Level, Innovation, and Obstacles to Growth. Who Needs a Weak Zloty?" Mimeo.

Cassiman B., Golovko E. (2007). "Innovation and the Export-Productivity Link". IESE Working Paper no 688.

Chidlow A., Salciuviene L, Young S., (2009). "Regional determinants of inward FDI distribution in Poland", International Business Review, Volume 18, Issue 2, 119-133.

Cieślik A. (2005), "Regional characteristics and the location of foreign firms within Poland Applied" Economics Volume 37, Issue 8, DOI: 10.1080/00036840500061087 pages 863-874.

Cieślik, A., Michałek, J.J., Michałek, A. , Mycielski, J. (2015). „Determinants of export performance: Comparison of Central European and Baltic firms". Czech Journal of Economics and Finance, 65(3), 211-229.

Cingano, F., Pinotti, P., (2012). "Trust, Firm Organization and the Structure of Production". Working Papers 053, Università Commerciale Luigi Bocconi.

Ciżkowicz P., Rzońca A., Umiński S. (2013), "The determinants of regional exports in Poland - a panel data analysis", Post-Communist Economies, 25(2), 206-224.

Clark C. (1940). "Conditions of Economic Progress", London: Macmillian.

Coci, S., Meliciani, V., Sabato, V. (2016). „Relationship lending and innovation: empirical evidence on a sample of European firms". Economics of Innovation and New Technology, 25(4), 335-357. DOI: 10.1080/10438599.2015.1062098.

Colli, A., García-Canal, E., \& Guillén, M. F. (2013). "Family character and international entrepreneurship: A historical comparison of Italian and Spanish 'new multinationals"”. Business History, 55(1), 119-138.

Correa-López, M, Doménech R. (2012). "The internationalisation of Spanish firms", BBVA Research Working Paper, Number 12/30.

Crespo N., Fortuna M.P. (2007). "Determinant Factors of FDI Spillovers - What Do We Really Know", World Development, 35(3), 410-425.

Damijan J., Kostevc Č., Rojec M. (2014). "Exporting Status and Success in Innovation: Evidence from Community Innovation Survey Micro Data for EU Countries", GRINCOH Working Paper, 2.06, Institute for Economic Research, Lubljana.

Daszkiewicz N., Wach K., (2014). "Motives for Going International and Entry Modes of Family Firms in Poland". Journal of Intercultural Management Vol. 6, No. 2, 5-18. 
Dimitratos P., Li Margaret N., D’Angelo F., A. (2013). "A Review of Current International Business and International Entrepreneurship Research and its Policy-making Implications", Final Report for Scottish Development International, Adam Smith Business School, University of Glasgow

Dissart, J. C. (2003). "Regional Economic Diversity and Regional economic Stability: Research Results and Agenda", International Regional Science Review, 26, 193-204.

Fasil, C. B. (2009). "Trade and growth: Selection versus process and product innovation", Working paper, European University Institute.

Fisher A. (1939). "Production, primary, secondary and tertiary", Economic Record 15.1, 24-38

Gajewski P. (2007). "Konwergencja regionalna w Polsce", ph.D. dissertation submitted to the Faculty of Economics and Sociology, University of Lodz.

Gajewski P. (2015). „Regionalne zróżnicowanie efektów impulsu polityki pieniężnej w Polsce”, Gospodarka Narodowa, 278(4), 27-47.

Gajewski P. (2016). „Regionalne krzywe Phillipsa w Polsce a efekty polityki pieniężnej”, Ekonomista, 214, 501-519.

Golovko, E., Valentini, F. (2011). "Exploring the complementarity between innovation and export for SMEs' growth", Journal of International Business Studies, 42 (3), 362-380.

Gorodnichenko Y., Svejnar J., Terrell K. (2014), "When does FDI have Positive Spillovers? Evidence from 17 Transition Market Economies", Journal of Comparative Economics, 42 (4), s. 954-969

Gorynia M., Trąbczyński P. (2014). “Determinanty bezpośrednich inwestycji zagranicznych, Ekonomista no. 5.

Guastella, G., Impano, F. (2016). "Knowledge, innovation, agglomeration and regional convergence in the EU: motivating place-based regional intervention", Review of Regional Research, 36(2), 121-143.

GUS (2015). „Działalność innowacyjna przedsiębiorstw w latach 2012-2014”, Urzad Statystyczny w Szczecinie.

Hagemejer J. (2015). "Productivity Spillovers in the GVC. The Case of Poland and the New EU Member States". Working Papers 2015-42, Faculty of Economic Sciences, University of Warsaw

Hanley A. Monreal-Pérez J.,(2012). “Can Spain learn from its 'export starters'?”. VoxEU.org, 5 November.

Kim S. Park D. (2011). “Ownership Structure and Export Performance: Firm-Level Evidence from the Republic of Korea", ADB Economics Working Paper Series, No. 295.

Koening P., Mayneris F., Poncet S. (2010). "Local exports spillovers in France", European Economic Review 54, 622-41.

Kostevc, C. (2015). "Ownership structure and firm export performance. Evidence from Slovenian microdata" Royal Institute of Technology, CESIS-Centre of Excellence for Science and Innovation Studies, No. 410.

Martin R.L., Sunley P. J. (2015). "On the notion of regional resilience: Conceptualization and explanation". Journal of Economic Geography, 15: 1-42.

Mayer, P., Ottaviano, G.I.P. (2007). "The happy few: the internationalization of European firms", Blueprint 3, Bruegel.

Melitz M.J. (2003). „The Impact of Trade on Intra-Industry Reallocations and Aggregate Industry Productivity", Econometrica (71), p. 1695-1725.

MliR (2015), Strategie ponadregionalne - wymiar terytorialny polityki rozwoju, https://www.mr.gov.pl/media/3355/20150312_strategie_ponadreg_wymiar_teryt.pdf 
Nakamura R., Taguchi M. (2011). "Agglomeration and Institutional Effects on Dynamics in Regional Disparities: Experience from Poland and Japan", Ekonomia, 28, 3-31.

Naude W., Gries T. (2009). "Explaining Regional Export Performance in a Developing Country: The Role of Geography and Relative Factor Endowments". Regional Studies, 43 (07), 967-979.

Navaretti B., Bugamelli G., M., Schivardi F., Altomonte C, Horgos D., Maggioni D. (2010). "The Global Operations of European Firms", Bruegel Blueprint Series.

Ottaviano, G. I. P. (2011). " 'New' new economic geography: firm heterogeneity and agglomeration economies Journal of Economic Geography", 11 (2), 231-240.

Rodil O., Vence., Sánchez M.(2015). "The relationship between innovation and export The case of Galician firms", Technological Forecasting \& Social Change, forthcoming.

Thomas K., Michael S. (2015). "Is specialization good for regional economic development?" Regional Studies, 49 (6), 1003-1018.

Tokarski T. (2008). "Taksonomiczne wskaźniki rozwoju ekonomicznego polskich województw”, Studia Prawno-Ekonomiczne, 78, 101-122.

Umiński S., Wojnicka-Sycz E., Brodzicki T., Gawlikowska-Hueckel K., Kwiatkowski J. (2015), Analiza branż o największym potencjale eksportowym w województwie pomorskim i badanie potrzeb w zakresie usług wsparcia eksportu przedsiębiorstw ze szczególnym uwzględnieniem branż elektrycznoelektronicznej/ICT, offshore/morskiej oraz farmaceutyczno-medycznokosmetycznej wraz z opracowaniem dotyczącym możliwości i sposobów podejmowania działań eksportowych na wybranych rynkach, Gdańsk, Sopot, 2015.

Wach K. (2014), "Familiness and Born Globals: Rapid Internationalisation among Polish Family Firms", Journal of Intercultural Management Vol. 6, No. 3, 177-186.

Wagner J. (2012). "The microstructure of the Great Export Collapse in German manufacturing industries, 2008/2009", University of Luneburg Working Paper Series in Economics, No.233

Wąsowska A. (2017). "Internationalisation of Family Firms: the Role of Ownership Structure and Composition of Top Management Team". Entrepreneurial Business and Economics Review, forthcoming.

Zou S., Stan S. (1998). "The determinants of export performance: a review of the empirical literature between 1987 and 1997", International Marketing Review, Vol. 15 (5), 333 - 356. 
ANNEX

Table A1. Employment specialization of voivodships in 2013 - 68 branches of industry and services

\begin{tabular}{|c|c|c|c|c|c|}
\hline & Moderate $-2<\left(E_{i} / E_{P L}\right)<3$ & Strong- $3<\left(E_{i} / E_{P L}\right)<4$ & Very strong - $\left(E_{i} / E_{P L}\right)>4$ & Krugman index & IIP index (\%) \\
\hline Dolnośląskie & $\begin{array}{l}\text { Electrical equipment } \\
\text { Motor vehicles, trailers and semi-trailers } \\
\text { Employment activities }\end{array}$ & & Mining of metal ores & 0.28 & 0.30 \\
\hline Kujawsko-Pomorskie & & Paper and paper products & & 0.25 & 0.25 \\
\hline Lubelskie & Civil engineering & & & 0.34 & 0.52 \\
\hline Lubuskie & $\begin{array}{l}\text { Wood and products of wood and cork, except } \\
\text { furniture; articles of straw and plaiting materials } \\
\text { Motor vehicles, trailers and semi-trailers }\end{array}$ & & & 0.32 & 0.35 \\
\hline Łódzkie & & Textiles & Wearing apparel & 0.26 & 0.28 \\
\hline Małopolskie & & & & 0.21 & 0.21 \\
\hline Mazowieckie & $\begin{array}{l}\text { Warehousing and support activities for } \\
\text { transportation } \\
\text { Activities of head offices; management } \\
\text { consultancy activities } \\
\text { Advertising and market research }\end{array}$ & & & 0.36 & 0.40 \\
\hline Opolskie & Electrical equipment & & & 0.34 & 0.38 \\
\hline Podkarpackie & Rubber and plastic products & & Other transport equipment & 0.28 & 0.27 \\
\hline Podlaskie & $\begin{array}{l}\text { Wood and products of wood and cork, except } \\
\text { furniture; articles of straw and plaiting materials } \\
\text { Machinery and equipment n.e.c. }\end{array}$ & & & 0.32 & 0.41 \\
\hline Pomorskie & Computer, electronic and optical products & & & 0.25 & 0.24 \\
\hline Śląskie & Motor vehicles, trailers and semi-trailers & Basic metals & Mining of coal and lignite & 0.37 & 1.98 \\
\hline Świętokrzyskie & & $\begin{array}{l}\text { Other non-metallic mineral } \\
\text { products }\end{array}$ & & 0.34 & 0.43 \\
\hline Warminsko-Mazurskie & $\begin{array}{l}\text { Wood and products of wood and cork, except } \\
\text { furniture; articles of straw and plaiting materials }\end{array}$ & & Furniture & 0.35 & 0.71 \\
\hline Wielkopolskie & Furniture & & & 0.23 & 0.31 \\
\hline Zachodniopomorskie & $\begin{array}{l}\text { Wood and products of wood and cork, except } \\
\text { furniture; articles of straw and plaiting materials }\end{array}$ & & & 0.27 & 0.22 \\
\hline
\end{tabular}

Note: Specialization determined based on the ratio of $i$-th region's employment in an industry $\left(E_{i}\right)$ to Poland's employment in the same industry $\left(E_{P L}\right)$. 